\title{
A genome-wide association for kidney function and endocrine-related traits in the NHLBI's Framingham Heart Study Shih-Jen Hwang1, Qiong Yang ${ }^{3}$, James B Meigs ${ }^{2}$, Elizabeth N Pearce ${ }^{4}$ and Caroline S Fox ${ }^{*}, 5$
}

\author{
Address: ${ }^{1}$ National Heart Lung and Blood Institutes, Bethesda, MD, USA, ${ }^{2}$ Massachusetts General Hospital and Harvard Medical School , Boston, \\ MA, USA, ${ }^{3}$ Department of Biostatistics, Boston University School of Public Health, Boston, MA, USA, ${ }^{4}$ Boston University School of Medicine, \\ Boston, MA, USA and ${ }^{5}$ Department of Endocrinology, Diabetes, and Hypertension, the Brigham and Women's Hospital, Harvard Medical School, \\ Boston, MA, USA \\ Email: Shih-Jen Hwang - hwangs2@nhlbi.nih.gov; Qiong Yang - qyang@bu.edu; James B Meigs - jmeigs@partner.org; \\ Elizabeth N Pearce - Elizabeth.pearce@bmc.org; Caroline S Fox* - foxca@nhlbi.nih.gov \\ * Corresponding author
}

Published: 19 September 2007

BMC Medical Genetics 2007, 8(SuppI I):SI0 doi:10.1186/147I-2350-8-SI-SI0

This article is available from: http://www.biomedcentral.com/I47I-2350/8/SI/SI0

(C) 2007 Hwang et al; licensee BioMed Central Ltd.

This is an open access article distributed under the terms of the Creative Commons Attribution License (http://creativecommons.org/licenses/by/2.0), which permits unrestricted use, distribution, and reproduction in any medium, provided the original work is properly cited.

\begin{abstract}
Background: Glomerular filtration rate (GFR) and urinary albumin excretion (UAE) are markers of kidney function that are known to be heritable. Many endocrine conditions have strong familial components. We tested for association between the Affymetrix GeneChip Human Mapping I00K single nucleotide polymorphism (SNP) set and measures of kidney function and endocrine traits.

Methods: Genotype information on the Affymetrix GeneChip Human Mapping I00K SNP set was available on $\mathrm{I} 345$ participants. Serum creatinine and cystatin-C (cysC; $n=98 \mathrm{I})$ were measured at the seventh examination cycle $(1998-2001)$; GFR $(n=1010)$ was estimated via the Modification of Diet in Renal Disease (MDRD) equation; UAE was measured on spot urine samples during the sixth examination cycle $(1995-1998)$ and was indexed to urinary creatinine $(n=822)$. Thyroid stimulating hormone (TSH) was measured at the third and fourth examination cycles (198I-1984; 1984-1987) and mean value of the measurements were used $(n=810)$. Age-sex-adjusted and multivariable-adjusted residuals for these measurements were used in association with genotype data using generalized estimating equations (GEE) and family-based association tests (FBAT) models. We presented the results for association tests using additive allele model. We evaluated associations with 70,987 SNPs on autosomes with minor allele frequencies of at least 0.10 , HardyWeinberg Equilibrium $p$-value $\geq 0.00 \mathrm{I}$, and call rates of at least $80 \%$.

Results: The top SNPs associated with these traits using the GEE method were rs 2839235 with GFR (p-value $\left.1.6 * 10^{-05}\right)$, rsII58I67 with cysC (p-value 8.5*10-09), rs 1712790 with UAE ( $\mathrm{p}$-value $\left.1.9 * 10^{-06}\right)$, and $\mathrm{rs} 6977660$ with TSH ( $\mathrm{p}$-value $3.7^{* 10} 10^{-06}$ ), respectively. The top SNPs associated with these traits using the FBAT method were rs6434804 with GFR(p-value $\left.2.4^{*} 10^{-5}\right)$, rs563754 with cysC ( $\mathrm{p}$-value $4.7^{*} 10^{-5}$ ), rs 1243400 with UAE ( $\mathrm{p}$-value $4.8^{*} 10^{-6}$ ), and rs 4128956 with TSH ( $\mathrm{p}$-value $3.6^{*}\left(0^{-5}\right)$, respectively. Detailed association test results can be found at http:// www.ncbi.nlm.nih.gov/projects/gap/cgi-bin/study.cgi?id=phs000007. Four SNPs in or near the CST3 gene were highly associated with cysC levels ( $\mathrm{p}$-value $8.5^{*} 10^{-09}$ to 0.007 ).
\end{abstract}


Conclusion: Kidney function traits and TSH are associated with SNPs on the Affymetrix GeneChip Human Mapping I00K SNP set. These data will serve as a valuable resource for replication as more SNPs associated with kidney function and endocrine traits are identified.

\section{Background}

Kidney disease affects 19 million adults in the United States [1]. Chronic kidney disease (CKD) is associated with cardiovascular disease [2-4], stroke [5], peripheral arterial disease [5,6], and all-cause mortality [7,8]. CVD risk factors are associated with the development of kidney disease [9], and the prevalence of traditional and novel CVD risk factors is elevated among those with kidney disease $[7,10]$. Urinary albumin excretion (UAE) is an early marker of kidney function that predicts CKD progression [11-14]. While glomerular filtration rate (GFR) and UAE are both measurements for kidney function, they represent different phenotypes and identify different subsets of at-risk individuals [15].

Genetic factors play a role in the progression of renal disease. Familial aggregation of end-stage renal disease has been identified [16]. Linkage analyses of kidney function have been conducted [17-21], and novel loci have been mapped to chromosomes 1 [18], 2 [21,22], 3 [17], 7 [22], $10[19,20,22]$, and 18 [22]. In the Framingham Heart Study, we have shown that kidney function is heritable [23], suggesting a role for genetic mechanisms in its etiology. Results of the linkage study from the Framingham Heart Study suggested linkage between kidney disease and a locus on chromosome 4 with a LOD score of 2.2 [23]. Familial clustering of UAE has been observed in siblings of subjects with diabetes [24], and UAE has been shown to be heritable among the offspring of diabetic subjects [25]. Genome-wide linkage analyses have mapped novel loci to chromosomes 12 [26] and 19 [26] among families enriched for hypertension. Among families with more severe forms of nephropathy, suggestive evidence for linkage has been found on chromosome 10p [27] and 9q3132 [28]. In the Framingham Heart Study, we observed a LOD score of 2.2 for UAE on chromosome 8 [29].

Thyroid disease, including Hashimoto's thyroiditis and Graves' disease, has a known familial component [30], and the same genes may underlie both conditions [31]. Measures of thyroid function have been shown to be heritable [32-34], and linkage has been reported to chromosome 18 for autoimmune thyroid disease in at least 2 studies $[35,36]$.

As part of the Framingham Heart Study 100K Project, we sought to test the relation of multiple kidney and endocrine traits to 70,987 SNPs. In this manuscript, we focus the results of association studies for GFR, UAE, cysC, and thyroid stimulating hormone (TSH), a sensitive measure of thyroid function.

\section{Methods}

Overall, 1345 participants were genotyped for the Affymetrix GeneChip Human Mapping 100K SNP set. For this manuscript, we focused on GFR from examination 7, UAE from examination 6 , serum cys $C$ from examination 7 , and mean TSH from examinations 3 and 4. Phenotypes were available in 1010 participants for GFR at exam cycle 7, 822 participants for UAE at exam cycle 6, 981 participants for cysC at exam cycle 7 , and 810 participants for mean TSH at exam cycles 3 and 4. Details about the selection process and genotyping are provided in the Overview [37]. Age-sex- and multivariable-adjusted residuals were generated; we present here only the results for multivariable-adjusted traits (all available results can be found in the website http://www.ncbi.nlm.nih.gov/projects/gap/cgibin/study.cgi?id=phs000007). We evaluated associations with 70,987 SNPs on autosomes with minor allele frequencies of at least 0.10 , HWE p-value $\geq 0.001$, and genotypic call rates of at least $80 \%$.

\section{Phenotype assessment}

Serum creatinine was measured using the modified Jaffe method at exams 2 (1978-1981), 5 (1991-1995), 6 (1995-1998), and 7 (1998-2001), and glomerular filtration rate (GFR) was estimated using the simplified Modification of Diet in Renal Disease Study equation [38,39]. CKD was defined based on the National Kidney Foundation Kidney Disease Outcome Quality Initiative working group, and modified slightly as previously described [9]. Urinary albumin concentration (UAE) was measured by immuno-turbidmetry (Tina-quant Albumin assay; Roche Diagnostics, Indianapolis, IN) during the sixth examination cycle (1995-1998). Urinary albumin was indexed to urinary creatinine (as the urine albumin/creatinine ratio, UACR) in order to account for differences in urine concentration. UACR is a validated and reliable single-sample measure of urinary albumin excretion and is highly correlated with albumin excretion rates assessed by 24-h urine collection [40,41]. Cystatin-C (cysC) was measured using particle enhanced immunonephelometry (Dade Behring BN 100 nephelometer; Dade Behring - Cystatin C reagent) with an inter-assay and intra-assay coefficient of variation of 3.3 and $2.4 \%$, respectively. We have previously published correlates of CKD in the Framingham Heart Study, including hypertension, diabetes, smoking, obesity, and low HDL cholesterol $[9,42]$. 
TSH was measured using a chemoluminescence assay (London Diagnostics, Eden Prairie, Minn) with a lower limit of detection of $0.01 \mathrm{mU} / \mathrm{L}$. Luteinizing hormone (LH), follicle stimulating hormone (FSH), and dehydroepiandrosterone sulfate (DHEAS) were measured as previously described $[43,44]$. Briefly, DHEAS concentrations were measured on serum samples via radioimmunoassay (Diagnostic Products Corp, CA). Calcium and phosphorous were measured at the second examination cycle using a standard colorimetric method (Roche Diagnostics, Alameda, CA), and uric acid was measured at the second examination cycle using an autoanalyzer with a phosphotungstic acid reagent.

\section{Genotyping}

Genotyping was performed using the $100 \mathrm{~K}$ Affymetrix GeneChip. Please see the Overview [37] for details.

\section{Statistical methods}

Phenotypes used for the analysis were created by generating normalized residuals. We generated both age-sex adjusted and multivariable adjusted residuals for each trait. Table 1 shows the covariates included in the multivariable adjustment; all data in this manuscript represents the multivariable-adjusted traits. All association analyses were performed using the generalized estimating equations or family based association tests; details are provided in the Overview [37]. Methods to verify family structure, generate identity-by-descent for these 1345 participants with genotype information as well as the markers used for linkage analysis, is detailed in the Overview [37]. To assess the clustering of significance between each SNP and phenotypes that were repeatedly measured in several examination cycles (see the third table in this article), we generated the geometric mean of p-values for SNPs that fit the following criteria: at least 4 out of 6 p-values of $<0.01$ in GEE or FBAT analyses for 6 GFR traits (change in serum creatinine from exam 2 to 7; GFR at exam 2; GFR at exam 5; GFR at exam 6; GFR at exam 7; mean GFR exams 2, 5, 6, 7); one out of two UACR traits (UACR; UACR in a sample enriched for hypertension); three out of three of TSH traits (TSH at exam 3; TSH at exam 4; mean TSH at exams 3 and 4). Among the GFR traits, Pearson correlation coefficients ranged from 0.18 ( $p<0.001$ ) between GFR at exam 2 and exam 7, to 0.77 $(\mathrm{p}<0.001)$ for the mean of GFR at exams 2, 5, 6, and 7 and GFR at exam 7 . Linkage analysis was performed using the variance components methods on a subset of $100 \mathrm{~K}$ markers and Marshfield short-tandem repeats; please see the Overview [37] for more details. Partial R², the adjusted percentage of the phenotype variation explained by the genotype variation, was estimated by subtracting the adjusted $\mathrm{R}^{2}$ value for a model that excludes the genotype from the $\mathrm{R}^{2}$ value for a model that includes the genotype.

\section{Results}

A description of all traits and phenotypes, including relevant examination cycles and multivariable-adjustments, is presented in Table 1. The median eGFR among individuals with CKD in our sample is $53.7 \mathrm{ml} / \mathrm{min} / 1.73 \mathrm{~m}^{2}$. Table 2a presents the top 25 SNPs with the lowest p-values obtained via GEE for GFR, cysC, UAE, and mean TSH; additional results can be found on the National Center for Biotechnology Information website http:// www.ncbi.nlm.nih.gov/projects/gap/cgi-bin/

study.cgi?id=phs000007. The top SNP associated with GFR, cysC, and UAE were rs2829235 (p-value $1.6 * 10^{-05}$ ), rs1158167 (p-value $8.5^{*} 10^{-09}$ ) near the cysC precursor gene family (CST3, CST4, CST9), and rs1712790 (p-value $1.9^{*} 10^{-06}$ ), respectively (Table $2 \mathrm{a}$ ). The top SNP to be associated with mean TSH was rs6977660 (p-value $\left.3.7^{*} 10^{-06}\right)$. Three SNPs were not shown on Table 2a due to the linkage disequilibrium (LD) $\left(\mathrm{r}^{2}>0.8\right)$ with the other top SNPs. These three SNPs were significantly associated with UAE at exam 6: rs9305355 (p-value $2.1^{*} 10^{-5}$ ) in LD with rs9305354, rs725304 (p-value $2.5^{*} 10^{-5}$ ) in LD with rs723464, and rs725307 (p-value $3.2^{*} 10^{-5}$ ) in LD with rs723464. Table $2 \mathrm{~b}$ presents the top SNPs based on the FBAT procedure. One SNP, rs $10511594\left(\mathrm{p}=9.0^{*} 10^{-5}\right)$ was in $\operatorname{LD}\left(\mathrm{r}^{2}>0.8\right)$ with $\mathrm{rs} 7865184\left(\mathrm{p}=4.0^{*} 10^{-5}\right)$ for mean TSH.

Table $2 c$ presents all traits examined with LOD scores of at least 2.5. One locus on chromosome 1 (nearest marker on the 100K GeneChip, rs10489578) was linked to GFR with a LOD score of 3.08. We observed a LOD score of 4.28 for uric acid to chromosome 2 (nearest marker rs10495487), a location we have previously identified using Marshfield linkage analysis to uric acid [45].

Table 3 presents the top SNPs for our multiple phenotype analysis for GFR, UAE, and TSH with a total of 24 SNPs showing consistently significant associations with multiple related phenotypes. Tables $4 \mathrm{a}$ and $4 \mathrm{~b}$ present results looking at replication of genes that have been associated with kidney traits in the published literature. Four SNPs in or near the CST3 gene were highly correlated with cysC levels ( $p$-value $8.5^{*} 10^{-09}$ to 0.007 ). All four SNPs have minor allele frequencies greater than $10 \%$ and none were in linkage disequilibrium (defined by $\mathrm{R}^{2}>0.8$ ) as shown on Table 4. The proportion of the cysC variation that can be explained by these SNPs is shown in Table 4 . rs 1158167 accounts for $2.5 \%$ of the cysC variation. We found nominal significance between a SNP near the APOE gene and CKD ( $\mathrm{p}=0.04)$.

\section{Additional findings}

We also identified several other plausible candidate genes that appear in our list of top 500 SNPs for each trait (see http://www.ncbi.nlm.nih.gov/projects/gap/cgi-bin/ 
Table I: Traits names, Framingham Heart Study examination cycle, and multivariable adjustments

\begin{tabular}{|c|c|c|c|c|}
\hline \multirow[t]{2}{*}{ Trait } & \multirow[t]{2}{*}{ Sample size } & \multicolumn{2}{|c|}{ Exam cycle/s } & \multirow[b]{2}{*}{ Adjustment ${ }^{\dagger}$} \\
\hline & & Offspring & Original Cohort & \\
\hline Serum Creatinine & $840-1010$ & $2,5,6,7$ & 0 & Age and sex; multivariable* \\
\hline Change in serum creatinine & 854 & 2,7 & 0 & Age and sex; multivariable* \\
\hline Glomerular Filtration Rate (GFR) & $840-1010$ & $2,5,6,7$ & 0 & Age and sex; multivariable* \\
\hline Chronic Kidney Disease & 1010 & 7 & 0 & Age and sex; multivariable* \\
\hline Cystatin C & 981 & 7 & 0 & Age and sex; multivariable* \\
\hline Uric acid & $912-1031$ & 1,2 & 0 & Age and sex; multivariable* \\
\hline Urinary Albumin Excretion & 822 & 6 & 0 & Age and sex; multivariable* \\
\hline $\begin{array}{l}\text { Urinary Albumin Excretion } \geq 30 \mathrm{mg} / \mathrm{g} \\
\text { Hypertension-enriched sample }\end{array}$ & 532 & 6 & 0 & Age and sex; multivariable* \\
\hline Serum Calcium & 906 & 2 & 0 & Age and sex; age, sex, serum creatinine \\
\hline Serum Phosphorus & 911 & 2 & 0 & Age and sex; age, sex, and serum creatinine \\
\hline Thyroid stimulation hormone (TSH) & 883 & 3 & 0 & $\begin{array}{l}\text { Age and sex; age, sex, body mass index, smoking, menopausal status, thyroid } \\
\text { hormone use }\end{array}$ \\
\hline Mean of TSH exam $3 \& 4$ & 810 & 3,4 & 0 & $\begin{array}{l}\text { Age and sex; age, sex, body mass index, smoking, menopausal status, thyroid } \\
\text { hormone use }\end{array}$ \\
\hline Luteinizing hormone $(\mathrm{LH})$ *** & 508 & 3 & 0 & Age and multivariable ${ }^{* * *}$ \\
\hline Follicle stimulating hormone $(\mathrm{FSH})$ *** & 509 & 3 & 0 & Age and multivariable**** \\
\hline Dehydroepiandrosterone sulfate (DHEAS) & 850 & 3 & 0 & Age and sex; multivariable ${ }^{* * * *}$ \\
\hline
\end{tabular}

*Multivariable adjustment include age, sex, systolic blood pressure, hypertension treatment, HDL-cholesterol, smoking, diabetes, body mass index **Men and post-menopausal women only with natural menopause not using hormone replacement treatment or oral contraceptive pills *** Age, diabetes mellitus, impaired fasting glucose, smoking, systolic blood pressure, diastolic blood pressure, body-mass index, hypertension treatment, prevalent cardiovascular disease, total cholesterol/HDL ratio and alcohol intake

study.cgi?id=phs000007). For GFR, we identified $L R P 1 B$ $($ GEE p-value $=0.0006$, rs1049688), ADRBK2 (GEE pvalue $=0.002$, rs1048312 $), A P O B($ GEE p-value $=0.003$, rs1048312), several genes in the chromosome 17 cytokine gene cluster including CCL3, CCL4, and CCL18 (GEE pvalue 0.004 , rs1818816), SCARB1 (GEE p-value $=0.004$, rs1902569), NFKB1 (FBAT p-value $=0.001$, rs230489), TGFB1 (FBAT p-value $=0.003$, rs2072239), and PPARG (FBAT p-value $=0.005$, rs709157). For UAE, we also identified a SNP in the LRP1B gene (GEE p-value $=0.004$, rs1049687). For cysC, we identified SNPs in the $L R P 1 B$ gene (GEE p-value $=0.001$, rs1463615), ANGPT1 (GEE pvalue $=0.005$, rs4354281), NFKB1 (FBAT p-value $=0.004$, rs2991716), and PPARG (FBAT p-value $=0.004$, rs1051041). For mean TSH, we identified SNPs in ADRBK2 (GEE p-value $=0.002$, rs3888397), TRHDE (GEE $\mathrm{p}$-value $=0.002$, rs2044305) and DIO2 (GEE p-value $=$ 0.003, rs54566), the SCD4 gene (rs10516679 GEE pvalue $=0.0007$ FBAT $\mathrm{p}$-value $=0.02)$, VLDLR (FBAT $\mathrm{p}$ value $=0.002$, rs4084415) and APOBEC2P (FBAT p-value $=0.005$, rs722442).

\section{Discussion}

In our analysis of kidney-related traits, we have found strong evidence for association between multiple kidneyrelated traits and TSH with SNPs on the Affymetrix $100 \mathrm{~K}$ GeneChip. We found strong evidence for association between cysC levels and 4 SNPs in or near the CST3 gene. For UAE, we observed strong association with ADAM23, a gene involved in the metalloproteinase family, which may be involved in the pathophysiology of glomerulosclerosis [46], and PCDH9, a gene that is a member of the cadherin superfamily. For TSH, we observed significant association with the HSPA4L gene with a mean p-value for all three TSH measurements, a gene that is part of the heat shock protein family, which may be involved in the pathophysiology of thyroid disease [47]. We also observed association with the SCD4 gene, a gene involved in the conversion of saturated to monounsaturated fatty acids; TSH is an important correlate of lipid levels [48].

In our linkage results, we observed a region we have previously noted for uric acid [45], albeit with a significantly higher LOD score. We identified a LOD score of 2.78 on chromosome 3, approximately $18 \mathrm{Mb}$ away from a region previously noted in association with kidney function in hypertensive individuals [17], a region that lies within our 1.5 support LOD interval. We also report novel loci for GFR and TSH.

We show significant association between cysC levels and the CST3 gene, an observation that has been previously noted [49]. Our top SNP reaches genome-wide significance, and may represent a true finding. In our candidate gene approach, we found nominal significance for a SNP near the APOE gene, a gene that has been associated with CKD [50]. Unfortunately, poor coverage of the APOE gene by the Affymetrix $100 \mathrm{~K}$ Genechip precluded a more indepth test of association with SNPs in the APOE gene and CKD.

Strengths of our study lie in our assessment of multiple measures of kidney function and endocrine traits in a sample unselected for these traits, thus reducing bias. We 
Table 2: Most significant results for GFR (examination 7), UAE (examination 6), cysC (examination 7), and mean TSH (examinations 3 and 4$)$ by GEE (2a), FBAT (2b) and linkage (2c) analyses

2a. Top 25 SNPs for association with GFR (examination 7), UAE (examination 6), cysC (examination 7), and mean TSH (examinations 3 and 4) based on the lowest $p$ value of the GEE test. Corresponding phenotype names on the web are GFRMV7 (GFR), UAELNMV6 (UAE), CYSCMV7 (CysC), and TSHMEAN34MV (TSH)

\begin{tabular}{|c|c|c|c|c|c|c|}
\hline TRAIT & SNP & Physical Location (Mb) & Chromosome & P value - FBAT & P value - GEE & GENE \\
\hline Cys C & rsII58167 & $23,526,189$ & 20 & 0.006 & $8.5 * 10-09$ & CST9L|CST9|CST3 \\
\hline UAE & rs $17 \mid 2790$ & $114,126,679$ & 11 & 0.014 & $1.9 * 10-06$ & FAM55B \\
\hline TSH & rs 6977660 & $19,578,720$ & 7 & 0.010 & $3.7 * 10^{-06}$ & \\
\hline TSH & rs9322817 & $105,338,926$ & 6 & 0.502 & $6.5 * 10^{-06}$ & HACEI \\
\hline TSH & rs10499559 & $21,882,699$ & 7 & 0.068 & $8.3 * 10^{-06}$ & RAPGEF5 \\
\hline UAE & rs9305354 & $28,397,067$ & 21 & 0.013 & $8.4 * 10^{-06}$ & \\
\hline Cys C & rs $214523 \mid$ & $23,573,547$ & 20 & 0.011 & $1.1 * 10^{-05}$ & CST9|CST3|CST4 \\
\hline UAE & rs723464 & $133,940,196$ & 4 & 0.000 & $1.1 * 10^{-05}$ & \\
\hline UAE & rs 2113379 & $207,177,180$ & 2 & 0.003 & $1.4 * 10-05$ & ADAM23 \\
\hline GFR & rs2839235 & $46,625,020$ & 21 & 0.055 & $1.6 * 10-05$ & PCNT2 \\
\hline TSH & rs 10493147 & $129,095,104$ & 4 & 0.040 & $2.1 * 10^{-05}$ & HSPA4L \\
\hline TSH & rs784490 & $39,148,534$ & 3 & 0.005 & $2.8 * 10-05$ & TTC2IA \\
\hline UAE & rs27802I & $6,698,929$ & 1 & 0.958 & $2.9 * 10-05$ & DNAJCII \\
\hline UAE & rs 1856190 & $33,598,615$ & 9 & 0.127 & $3.0 * 10-05$ & \\
\hline UAE & rs 10485409 & $91,562,132$ & 6 & 0.147 & $3.1 * 10^{-05}$ & \\
\hline UAE & rs 2785980 & $216,088,914$ & 1 & $4.8 * 10^{-04}$ & $3.7 * 10-05$ & \\
\hline UAE & rs837678 & $191,168,583$ & 3 & 0.012 & $3.8 * 10-05$ & LEPRELI \\
\hline GFR & rs 3095160 & $49,844,269$ & 13 & 0.002 & $3.8 * 10-05$ & \\
\hline UAE & rs $276|17|$ & $99,278,898$ & 13 & 0.078 & $4.1 * 10^{-05}$ & CLYBL \\
\hline GFR & rs 10507344 & $24,623,069$ & 13 & 0.017 & $4.1 * 10^{-05}$ & PABPC3 \\
\hline GFR & rs890945 & $|57,924,80|$ & 5 & 0.036 & $4.7 * 10-05$ & \\
\hline UAE & rs 10502192 & $114,127,562$ & 11 & 0.051 & $4.9 * 10-05$ & FAM55B \\
\hline GFR & rs 10489639 & $157,492,600$ & 1 & 0.194 & $4.9 * 10-05$ & CD48 \\
\hline TSH & rs 9308765 & $118,759,439$ & 2 & 0.353 & $5.1 * 10^{-05}$ & \\
\hline TSH & rs3908399 & $12,849,275$ & 20 & $8.0^{*} 10^{-04}$ & $5.2 * 10-05$ & \\
\hline
\end{tabular}

2b. Top 25 SNPs for association with GFR (examination 7), UAE (examination 6), cysC (examination 7), and mean TSH (examinations 3 and 4) based on the lowest p-value of the FBAT test. Corresponding phenotype names on the web are GFRMV7 (GFR), UAELNMV6 (UAE), CYSCMV7 (CysC), and TSHMEAN34MV (TSH)

\begin{tabular}{|c|c|c|c|c|c|c|}
\hline TRAIT & SNP & Physical Location (Mb) & Chromosome & $P$ value - FBAT & $P$ value - GEE & GENE \\
\hline GEE & GENE & & & & & \\
\hline UAE & rs 1243400 & $9,016,664$ & 10 & $4.8 * 10-06$ & 0.036 & \\
\hline UAE & rs827640 & $9,028,017$ & 10 & $1.5 * 10-05$ & 0.047 & \\
\hline
\end{tabular}


Table 2: Most significant results for GFR (examination 7), UAE (examination 6), cysC (examination 7), and mean TSH (examinations 3 and 4) by GEE (2a), FBAT (2b) and linkage (2c) analyses (Continued)

\begin{tabular}{|c|c|c|c|c|c|c|}
\hline UAE & rs73I5682 & $32,577,224$ & 12 & $2.1 * 10^{-05}$ & 0.28 & FGD4 \\
\hline GFR & rs 6434804 & $196,589,899$ & 2 & $2.4 * 10-05$ & 0.003 & DNAH7 \\
\hline UAE & rsI543468 & $230,655,160$ & 1 & $2.5 * 10-05$ & 0.253 & SLC35F3 \\
\hline UAE & rs723464 & $133,940,196$ & 4 & $2.7^{*} 10^{-05}$ & $1.0 * 10-05$ & \\
\hline TSH & rs4I28956 & $13 \mid, 848,063$ & 9 & $3.6 * 10^{-05}$ & 0.355 & \\
\hline TSH & rs7865।84 & $14,677,867$ & 9 & $3.9 * 10-05$ & 0.082 & ZDHHC2I \\
\hline CysC & rs5637754 & $61,068,849$ & 18 & $4.7 * 10-05$ & 0.002 & \\
\hline GFR & rs2885618 & $41,244,839$ & 18 & $4.8 * 10-05$ & $1.0 * 10-04$ & \\
\hline TSH & rs701801 & $100,166,859$ & 10 & $5.8 * 10^{-05}$ & 0.090 & HPSI \\
\hline UAE & rs 33855 & $171,124,642$ & 5 & $6.2 * 10^{-05}$ & 0.192 & \\
\hline GFR & rs1048374l & $61,059,454$ & 14 & $6.3 * 10-05$ & 0.298 & PRKCH \\
\hline CysC & $r s 2121267$ & $46,461,040$ & 2 & $6.6 * 10-05$ & 0.002 & EPASI \\
\hline CysC & rsI 400306 & $83,256,163$ & 11 & $7.2 * 10-05$ & 0.061 & \\
\hline TSH & rs|223531 & $|3,255,52|$ & 6 & $8.0 * 10-05$ & 0.123 & PHACTRI \\
\hline CysC & rs 10504244 & $59,147,328$ & 8 & $8.3 * 10^{-05}$ & 0.005 & \\
\hline UAE & rs2374688 & $106,175,669$ & 12 & $9.1 * 10^{-05}$ & 0.087 & BTBDII \\
\hline UAE & rs 10519012 & $58,333,458$ & 15 & $1.0 * 10-04$ & 0.088 & \\
\hline CysC & rs1931619 & $82,682,388$ & 6 & $1.0 * 10^{-04}$ & 0.05 & \\
\hline UAE & rs 10501264 & $41,387,406$ & 11 & $1.1 * 10^{-04}$ & $7.2 * 10^{-04}$ & \\
\hline UAE & rs 10492025 & $111,735,770$ & 12 & $1.1 * 10^{-04}$ & 0.41 & $\mathrm{RPH} 3 \mathrm{~A}$ \\
\hline UAE & rs2056694 & $128,5 \mid 7,768$ & 7 & $1.1 * 10^{-04}$ & 0.1 & \\
\hline UAE & rs81।13386 & $|6,332,87|$ & 19 & $1.1 * 10^{-04}$ & 0.053 & KLF2 \\
\hline TSH & rs295136 & $200,966,508$ & 2 & $1.3 * 10^{-04}$ & 0.64 & \\
\hline
\end{tabular}

2c. Magnitude and Location of Peak LOD scores for regions in which LOD exceeds 2.5.* Corresponding phenotype names on the web are PHOSPHORUSMV2 (serum phosphorous), URICACIDMV2 (uric acid), SCRLNMVNL6 (serum creatinine exam 6), LHMV3 (luteinizing hormone), GFRMVNL6 (GFR exam 6), CALCIUMMV2 (serum calcium), GFRMV7 (GFR exam 7), and SCRLNMVNL5 (serum creatinine exam 5)

\begin{tabular}{|c|c|c|c|c|c|c|}
\hline Trait & SNP & Chromosome & $\begin{array}{c}\text { Physical } \\
\text { location (Mb) }\end{array}$ & $\begin{array}{c}\text { LOD I.5 } \\
\text { (Lower; Mb) }\end{array}$ & $\begin{array}{c}\text { LOD I.5 } \\
\text { (Upper; Mb) }\end{array}$ & LOD \\
\hline Serum Phosphorous & rs754958 & 8 & 134307953 & $|304| 3367$ & 139409406 & 4.33 \\
\hline Uric acid & rs 10495487 & 2 & 2310945 & $10724 \mid$ & 3787803 & 4.28 \\
\hline Serum creatinine (exam 6) & rs 10489578 & 1 & 229251990 & 224108350 & 230301885 & 3.35 \\
\hline Luteinizing Hormone & rs 10515134 & 17 & 52218447 & 45043525 & 59136652 & 3.17 \\
\hline GFR (exam 6) & rsl0489578 & 1 & 229251990 & $22088 \mid 707$ & 230301885 & 3.08 \\
\hline Serum Calcium & rs 10484370 & 6 & 18686366 & 10181754 & 21792915 & 3.03 \\
\hline GFR (exam 7) & rs 10511176 & 3 & 100809191 & 73551217 & 103238533 & 2.79 \\
\hline Serum creatinine (exam 5) & rsl0502302 & 18 & 2542886 & 156277 & 3857290 & 2.51 \\
\hline
\end{tabular}

*All traits are multivariable-adjusted; see Table I for specific covariate adjustments. 
Table 3: SNPs showing the top 8 significant association with multiple measurements of GFR, UACR, or TSH phenotypes.* Corresponding phenotype names on the web are GFRMV7 (GFR), UAELNMV6 (UAE), and TSHMEAN34MV (TSH).

\begin{tabular}{|c|c|c|c|c|c|c|}
\hline Trait & chromosome & SNP (rsID) & Physical Location & Genes (in or near) & Mean p-value (GEE) & Mean p-value (FBAT) \\
\hline GFR & 21 & rs2839235 & 46625020 & PCNT2 & $6.3 * 10^{-4}$ & 0.281 \\
\hline GFR & 17 & rs 10512437 & 27046466 & & 0.002 & 0.197 \\
\hline GFR & 13 & rs2480555 & 70785310 & $\mathrm{DACHI}$ & 0.003 & 0.006 \\
\hline GFR & 7 & rs 10486135 & 11301740 & & 0.004 & 0.142 \\
\hline GFR & 7 & rs727087 & 8244570 & $|C A|$ & 0.004 & 0.223 \\
\hline GFR & 13 & rs1005066 & 70790573 & $\mathrm{DACHI}$ & 0.004 & 0.022 \\
\hline GFR & 18 & rs2885618 & 41244839 & SETBPI & 0.004 & 0.024 \\
\hline GFR & 2 & rs10496887 & |42|9857| & $L R P I B$ & 0.005 & 0.091 \\
\hline UAE & 11 & rs 1712790 & $1|4| 26679$ & FAM55D & $9.1 * 10-07$ & 0.009 \\
\hline UAE & 6 & rs 10485409 & 91562132 & EPHA7 & $1.0 * 10-05$ & 0.067 \\
\hline UAE & 21 & rs9305354 & 28397067 & & $1.9 * 10-05$ & 0.018 \\
\hline UAE & 11 & rs 10502192 & 114127562 & FAM55D & $3.6 * 10-05$ & 0.041 \\
\hline UAE & 1 & rs2077678 & 75246848 & & $4.4 * 10-05$ & 0.022 \\
\hline UAE & 4 & rs723464 & 133940196 & & $4.9 * 10-05$ & 0.000 \\
\hline UAE & 21 & rs9305355 & 28397088 & & $5.0 * 10-05$ & 0.011 \\
\hline UAE & 6 & rs10484587 & $143 \mid 83270$ & $A I G I$ & $5.2 * 10-05$ & 0.032 \\
\hline TSH & 7 & rs6977660 & 19578720 & & $1.6 * 10-05$ & 0.022 \\
\hline TSH & 4 & rs10493|47 & 129095104 & HSPA4L & $2.1 * 10-05$ & 0.019 \\
\hline TSH & 7 & rs10499559 & 21882699 & DNAHII & $2.8 * 10-05$ & 0.111 \\
\hline TSH & 6 & rs9322817 & 105338926 & & $7.4 * 10-05$ & 0.576 \\
\hline TSH & 2 & rs9308765 & 118759439 & INSIGZ & $7.7 * 10-05$ & 0.404 \\
\hline TSH & 6 & rs694223I & 105298507 & & $1.6 * 10-04$ & 0.541 \\
\hline TSH & 7 & rs 10486365 & 19574604 & & $1.9 * 10-04$ & 0.221 \\
\hline TSH & 7 & rs 10486653 & 34484903 & BMPER & $2.7 * 10^{-04}$ & 0.252 \\
\hline
\end{tabular}

*see details in methods for criteria for generating mean p-value

Table 4: Results on Association Analysis for Candidate Genes

4a. Results of GEE analysis between SNPs in the CST3 and APOE candidate genes and the kidney function traits with p-value < 0.05. Corresponding phenotype names on the web are CYSMV7 (CysC) and CKDMV7 (CKD).

\begin{tabular}{|c|c|c|c|c|c|c|c|}
\hline $\begin{array}{l}\text { Candidate } \\
\text { gene }\end{array}$ & PHENOTYPE & SNP & $\begin{array}{c}\text { CHROMOSO } \\
\text { ME }\end{array}$ & Location & $\begin{array}{l}\text { Minor allele } \\
\text { frequency(\%) }\end{array}$ & $\begin{array}{l}\text { P_value } \\
\text { (GEE) }\end{array}$ & Partial $\mathbf{R}^{2}$ \\
\hline CST3 & CysC & rsII58I67 & 20 & $23,526,189$ & 21 & $8.0 * 10-9$ & 2.5 \\
\hline CST3 & CysC & rs2|4523| & 20 & $23,573,547$ & 15 & $1.1 * 10-5$ & 1.2 \\
\hline CST3 & CysC & rs726217 & 20 & $23,532,116$ & 38 & $3.1 * 10^{-4}$ & 0.8 \\
\hline CST3 & CysC & rs91।I22 & 20 & $23,573,746$ & 37 & 0.007 & 1.1 \\
\hline$A P O E$ & CKD & rs3760626 & 19 & $50,148,945$ & 45 & 0.04 & - \\
\hline
\end{tabular}

4b. Results of FBAT analysis between SNPs in the CST3 candidate gene and kidney function traits with p-value $<0.05$. Corresponding phenotype names on the web are CYSMV7 (CysC) and UAEGE30HTNMV6 (UAE $\geq 30 \mathrm{mg} / \mathrm{g}$ )

\begin{tabular}{lllccc}
\hline $\begin{array}{l}\text { Candidate } \\
\text { gene }\end{array}$ & PHENOTYPE & SNP & $\begin{array}{c}\text { CHROMOSO } \\
\text { ME }\end{array}$ & Location & P-value \\
\hline CST3 & CysC & rsII58I67 & 20 & $23,526,189$ & 0.006 \\
CST3 & CysC & rs2145231 & 20 & $23,573,547$ & 0.011 \\
CST3 & UAE $\geq 30^{*}$ & rs9lII22 & 20 & $23,573,746$ & 0.032 \\
\hline
\end{tabular}

\footnotetext{
*In a sample enriched for hypertensive individuals
} 
also have excellent assessment of potential confounders that we are able to adjust for in our residual creation. Because the Framingham Heart Study has measured multiple traits, we are able to examine phenotype clustering. Limitations exist as well. Kidney function was ascertained by a single serum creatinine measure, which may lead to misclassification. Our sample was not selected for CKD, and as a result, affected individuals had moderate CKD as reflected by the median eGFR of $53.7 \mathrm{ml} / \mathrm{min} / 1.73 \mathrm{~m}^{2}$ among participants with CKD. The MDRD equation, which was used to estimate GFR, has been shown to underestimate GFR by $29 \%$ in healthy individuals [51]; therefore, we may have introduced additional misclassification into our trait definition. We used a spot urine specimen to assess UAE instead of a 24-hour collection. However, spot UAE approximates 24-hour collections [40], and are not prone to the error inherent in collecting 24-hour urine specimens. We used cysC as a continuous trait and did not use transforming equations to estimate GFR, as most existing equations have been developed in small, selected samples $[52,53]$, or developed using immunoturbimetric method $[53,54]$ instead of nephelometry and therefore we did not feel as though they were appropriate for use in our large population-based cohort. Further, we used cystatin $\mathrm{C}$ as a marker of kidney function but can not rule out that it may also reflect cardiovascular disease risk above and beyond its relation to kidney function [55-59]. Our focus on multivariable models may have led us to miss important bivariate associations between SNPs and measures of kidney function. Given that our findings have not yet been replicated, many p-values may represent false positive findings. We used TSH as an indicator of thyroid function, as we do not have measures of free thyroxine or a reliable assessment of thyroid disease in our study sample. Our sample is neither ethnically diverse nor nationally representative, and it is uncertain how our results would apply to other ethnic groups. However, in genetics studies, sample homogeneity is beneficial in order to reduce population stratification. For limitations pertaining to our genotyping or statistical methods, please see the Overview [37].

\section{Conclusion}

Kidney function traits and TSH are associated with SNPs on the Affymetrix 100K SNP GeneChip. Replication of association between these traits and SNPs requires followup in independent samples. These data will serve as a valuable resource for replication as more SNPs associated with kidney function and endocrine traits are identified.

\section{Abbreviations}

$\mathrm{CKD}=$ chronic kidney disease; cysC $=$ cystatin- $\mathrm{C}$; DHEAS = dehydroepiandrosterone sulfate; FBAT $=$ family-based association tests; FSH = follicle stimulating hormone; GEE = generalized estimating equations; GFR = glomerular fil- tration rate; $\mathrm{LD}=$ linkage disequilibrium; $\mathrm{LH}=$ luteinizing hormone; $\mathrm{MDRD}=$ Modification of Diet in Renal Disease; SNP $=$ single nucleotide polymorphism; $\mathrm{TSH}=$ thyroid stimulating hormone; UAE = urinary albumin excretion.

\section{Competing interests}

The authors declare that they have no competing interests.

\section{Authors' contributions}

SH generated the phenotype data, participated in the analysis, and drafted the manuscript. CF helped generate the phenotype data, interpret the results, and draft the manuscript. QY generated the phenotype data, interpreted the results, and helped draft the manuscript. JBM helped generate the phenotype data, interpret the results, and revised the manuscript critically for important intellectual content; and has given final approval of the version to be published. EP assisted in the acquisition and cleaning of the TSH data and critically reviewed a draft of the manuscript. All authors gave final approval to the manuscript.

\section{Acknowledgements}

The Framingham Study is supported by NOI-HC 25195. Dr Meigs is supported by an American Diabetes Association Career Development Award. The study was also supported by donation of urinary albumin excretion assay reagents from Roche Diagnostics Inc. A portion of the research was conducted using the BU Linux Cluster for Genetic Analysis (LinGA) funded by the NIH NCRR (National Center for Research Resources) Shared Instrumentation grant (ISIORR I63736-0IAI). The investigators would like to recognize the Framingham Heart Study participants and the following collaborators: Martin Larson, Daniel Levy, Emelia J. Benjamin, Joanne M. Murabito, and Ramachandran S. Vasan.

This article has been published as part of BMC Medical Genetics Volume 8 Supplement I, 2007: The Framingham Heart Study 100,000 single nucleotide polymorphisms resource. The full contents of the supplement are available online at $h t t p: / / w w w . b i o m e d c e n t r a l . c o m / / 47 \mid-2350 / 8$ ? issue=SI.

\section{References}

I. Coresh J, Astor BC, Greene T, Eknoyan G, Levey AS: Prevalence of chronic kidney disease and decreased kidney function in the adult US population: Third National Health and Nutrition Examination Survey. Am J Kidney Dis 2003, 4I:I-I2.

2. Manjunath G, Tighiouart H, Ibrahim H, MacLeod B, Salem DN, Griffith JL, Coresh J, Levey AS, Sarnak MJ: Level of kidney function as a risk factor for atherosclerotic cardiovascular outcomes in the community. J Am Coll Cardiol 2003, 41:47-55.

3. Manjunath G, Tighiouart H, Coresh J, MacLeod B, Salem DN, Griffith JL, Levey AS, Sarnak MJ: Level of kidney function as a risk factor for cardiovascular outcomes in the elderly. Kidney Int 2003, 63:1 I2I-1I29.

4. Mann JF, Gerstein HC, Pogue J, Bosch J, Yusuf S: Renal insufficiency as a predictor of cardiovascular outcomes and the impact of ramipril: the HOPE randomized trial. Ann Intern Med 200I, 134:629-636.

5. Fried LF, Shlipak MG, Crump C, Bleyer AJ, Gottdiener JS, Kronmal RA, Kuller LH, Newman AB: Renal insufficiency as a predictor of cardiovascular outcomes and mortality in elderly individuals. J Am Coll Cardiol 2003, 41: 1364-1372.

6. O'Hare AM, Vittinghoff E, Hsia J, Shlipak MG: Renal insufficiency and the risk of lower extremity peripheral arterial disease: results from the heart and estrogen/progestin replacement study (HERS). J Am Soc Nephrol 2004, I 5: 1046- I05I. 
7. Weiner DE, Tighiouart H, Amin MG, Stark PC, MacLeod B, Griffith JL, Salem DN, Levey AS, Sarnak MJ: Chronic kidney disease as a risk factor for cardiovascular disease and all-cause mortality: a pooled analysis of community-based studies. J Am Soc Nephrol 2004, 15:1307-1315.

8. Culleton BF, Larson MG, Wilson PW, Evans JC, Parfrey PS, Levy D: Cardiovascular disease and mortality in a community-based cohort with mild renal insufficiency. Kidney Int 1999, 56:2214-2219.

9. Fox CS, Larson MG, Leip EP, Culleton B, Wilson PW, Levy D: Predictors of new-onset kidney disease in a community-based population. JAMA 2004, 291:844-850.

10. Muntner P, Hamm LL, Kusek JW, Chen J, Whelton PK, He J: The prevalence of nontraditional risk factors for coronary heart disease in patients with chronic kidney disease. Ann Intern Med 2004, 140:9-17.

II. Adler Al, Stevens RJ, Manley SE, Bilous RW, Cull CA, Holman RR: Development and progression of nephropathy in type 2 diabetes: The United Kingdom Prospective Diabetes Study (UKPDS 64). Kidney Int 2003, 63:225-232.

12. Nelson RG, Bennett PH, Beck GJ, Tan M, Knowler WC, Mitch WE, Hirschman GH, Myers BD: Development and progression of renal disease in Pima Indians with non-insulin-dependent diabetes mellitus. Diabetic Renal Disease Study Group. N Engl J Med 1996, 335:1636-1642.

13. Peterson JC, Adler S, Burkart JM, Greene T, Hebert LA, Hunsicker LG, King AJ, Klahr S, Massry SG, Seifter JL: Blood pressure control, proteinuria, and the progression of renal disease. The Modification of Diet in Renal Disease Study. Ann Intern Med 1995, 123:754-762.

14. Maschio G, Alberti D, Janin G, Locatelli F, Mann JF, Motolese M, Ponticelli C, Ritz E, Zucchelli P: Effect of the angiotensin-convertingenzyme inhibitor benazepril on the progression of chronic renal insufficiency. The Angiotensin-Converting-Enzyme Inhibition in Progressive Renal Insufficiency Study Group. N Engl J Med 1996, 334:939-945.

15. Garg AX, Kiberd BA, Clark WF, Haynes RB, Clase CM: Albuminuria and renal insufficiency prevalence guides population screening: results from the NHANES III. Kidney Int 2002, 61:2165-2175.

16. Lei HH, Perneger TV, Klag MJ, Whelton PK, Coresh J: Familial aggregation of renal disease in a population-based case-control study. J Am Soc Nephrol 1998, 9: I270-1276.

17. DeWan AT, Arnett DK, Atwood LD, Province MA, Lewis CE, Hunt SC, Eckfeldt J: A genome scan for renal function among hypertensives: the HyperGEN study. Am J Hum Genet 200I, 68: $136-144$.

18. Cohn DH, Shohat T, Yahav M, Ilan T, Rechavi G, King L, Shohat M: A locus for an autosomal dominant form of progressive renal failure and hypertension at chromosome Iq2I. Am J Hum Genet 2000, 67:647-65I

19. Freedman BI, Rich SS, Yu H, Roh BH, Bowden DW: Linkage heterogeneity of end-stage renal disease on human chromosome I0. Kidney Int 2002, 62:770-774.

20. Hunt SC, Hasstedt SJ, Coon H, Camp NJ, Cawthon RM, Wu LL, Hopkins PN: Linkage of creatinine clearance to chromosome 10 in Utah pedigrees replicates a locus for end-stage renal disease in humans and renal failure in the fawn-hooded rat. Kidney Int 2002, 62: I|43-I|48.

21. Hunt SC, Coon H, Hasstedt SJ, Cawthon RM, Camp NJ, Wu LL, Hopkins PN: Linkage of serum creatinine and glomerular filtration rate to chromosome $\mathbf{2}$ in Utah pedigrees. Am J Hypertens 2004, I 7:5II-5I5.

22. Placha G, Poznik GD, Dunn J, Smiles A, Krolewski B, Glew T, Puppala $S$, Schneider J, Rogus JJ, Rich SS, Duggirala R, Warram JH, Krolewski AS: A genome-wide linkage scan for genes controlling variation in renal function estimated by serum cystatin $C$ levels in extended families with type 2 diabetes. Diabetes 2006, 55:3358-3365

23. Fox CS, Yang Q, Cupples LA, Guo CY, Larson MG, Leip EP, Wilson PW, Levy D: Genomewide Linkage Analysis to Serum Creatinine, GFR, and Creatinine Clearance in a Community-Based Population: The Framingham Heart Study. J Am Soc Nephrol 2004, I5:2457-246I.

24. Pontiroli AE, Monti LD, Pizzini A, Piatti P: Familial clustering of arterial blood pressure, HDL cholesterol, and pro-insulin but not of insulin resistance and microalbuminuria in siblings of patients with type 2 diabetes. Diabetes Care 2000, 23:1359-1364.

25. Forsblom CM, Kanninen T, Lehtovirta M, Saloranta C, Groop LC: Heritability of albumin excretion rate in families of patients with Type II diabetes. Diabetologia 1999, 42:1359-1366.

26. Freedman BI, Beck SR, Rich SS, Heiss G, Lewis CE, Turner S, Province MA, Schwander KL, Arnett DK, Mellen BG: A genome-wide scan for urinary albumin excretion in hypertensive families. Hypertension 2003, 42:29I-296.

27. lyengar SK, Fox KA, Schachere M, Manzoor F, Slaughter ME, Covic AM, Orloff SM, Hayden PS, Olson JM, Schelling JR, Sedor JR: Linkage analysis of candidate loci for end-stage renal disease due to diabetic nephropathy. J Am Soc Nephrol 2003, I 4:SI95-S20I.

28. Chung KW, Ferrell RE, Ellis D, Barmada M, Moritz M, Finegold DN, Jaffe R, Vats A: African American hypertensive nephropathy maps to a new locus on chromosome $9 q 3 \mathrm{I}-\mathbf{q} 32$. Am J Hum Genet 2003, 73:420-429.

29. Fox CS, Yang Q, Guo CY, Cupples LA, Wilson PW, Levy D, Meigs JB: Genome-wide linkage analysis to urinary microalbuminuria in a community-based sample: The Framingham Heart Study. Kidney Int 2005, 67:70-74

30. Hall R, Stanbury JB: Familial studies of autoimmune thyroiditis. Clin Exp Immunol 1967, 2(Suppl-25):

3I. Tomer Y, Barbesino G, Greenberg DA, Concepcion E, Davies TF: Mapping the major susceptibility loci for familial Graves' and Hashimoto's diseases: evidence for genetic heterogeneity and gene interactions. J Clin Endocrinol Metab 1999, 84:4656-4664.

32. Samollow PB, Perez G, Kammerer CM, Finegold D, Zwartjes PW, Havill LM, Comuzzie AG, Mahaney MC, Goring HH, Blangero J, Foley TP, Barmada MM: Genetic and environmental influences on thyroid hormone variation in Mexican Americans. J Clin Endocrinol Metab 2004, 89:3276-3284.

33. Hansen PS, Brix TH, Sorensen TI, Kyvik KO, Hegedus L: Major genetic influence on the regulation of the pituitary-thyroid axis: a study of healthy Danish twins. J Clin Endocrinol Metab 2004, 89: I I8I-II 87.

34. Meikle AW, Stringham JD, Woodward MG, Nelson JC: Hereditary and environmental influences on the variation of thyroid hormones in normal male twins. J Clin Endocrinol Metab 1988, 66:588-592.

35. Vaidya B, Imrie H, Perros P, Young ET, Kelly WF, Carr D, Large DM, Toft AD, Kendall-Taylor P, Pearce SH: Evidence for a new Graves disease susceptibility locus at chromosome I8q2I. Am J Hum Genet 2000, 66:1710-1714.

36. Hadj KH, Rebai A, Kaffel N, Abid M, Ayadi H: Evidence for linkage and association between autoimmune thyroid diseases and the $|8 q| 2-q 2 I$ region in a large Tunisian family. Int J Immunogenet 2006, 33:25-32.

37. Cupples LA, Arruda H, Benjamin EJ, D'Agostino RB Sr, Demissie S, DeStefano AL, Dupuis J, Falls K, Fox CS, Gottlieb DJ, Govindaraju DR, Guo CY, Hwang SJ, Kathiresan S, Kiel DP, Larson MG, Laramie JM, Levy D, Lunetta KL, Mailman MD, Manning AK, Meigs JB, Murabito JM, Newton-Cheh C, O'Connor GT, O'Donnell C], Pandey MA, Qiong Y, Seshadri S, Vasan RS, Wang ZY, Wolf PA, Atwood LD: The Framingham Heart Study 100K SNP genome-wide association study resource: Overview of 17 phenotype working group reports. BMC Med Genet 2007, 8(SuppI I):SI.

38. Levey AS, Bosch JP, Lewis JB, Greene T, Rogers N, Roth D: A more accurate method to estimate glomerular filtration rate from serum creatinine: a new prediction equation. Modification of Diet in Renal Disease Study Group. Ann Intern Med 1999, 130:46 I-470

39. K/DOQI clinical practice guidelines for chronic kidney disease : evaluation, classification, and stratification. Kidney Disease Outcome Quality Initiative. Am J Kidney Dis 2002, 39:SI-246.

40. Nathan DM, Rosenbaum C, Protasowicki VD: Single-void urine samples can be used to estimate quantitative microalbuminuria. Diabetes Care 1987, 10:414-418.

4I. Bakker AJ: Detection of microalbuminuria. Receiver operating characteristic curve analysis favors albumin-to-creatinine ratio over albumin concentration. Diabetes Care 1999 22:307-3।3.

42. Parikh NI, Hwang SJ, Larson MG, Meigs JB, Levy D, Fox CS: Cardiovascular disease risk factors in chronic kidney disease: over- 
all burden and rates of treatment and control. Arch Intern Med 2006, I66:1884-189|.

43. Amin S, Zhang Y, Sawin CT, Evans SR, Hannan MT, Kiel DP, Wilson PW, Felson DT: Association of hypogonadism and estradiol levels with bone mineral density in elderly men from the Framingham study. Ann Intern Med 2000, I33:951-963.

44. Arnlov J, Pencina MJ, Amin S, Nam BH, Benjamin EJ, Murabito JM, Wang TJ, Knapp PE, D'Agostino RB Sr, Bhasin S, Vasan RS: Endogenous sex hormones and cardiovascular disease incidence in men. Ann Intern Med 2006, I 45: I76-I84.

45. Yang Q, Guo CY, Cupples LA, Levy D, Wilson PW, Fox CS: Genome-wide search for genes affecting serum uric acid levels: the Framingham Heart Study. Metabolism 2005, 54:|435-|44|.

46. Camp TM, Smiley LM, Hayden MR, Tyagi SC: Mechanism of matrix accumulation and glomerulosclerosis in spontaneously hypertensive rats. J Hypertens 2003, 2 1:1719-1727.

47. Ginsberg J, Labedz T, Brindley DN: Phosphorylation of Heat Shock Protein-90 by TSH in FRTL-5 Thyroid Cells. Thyroid 2006, I 6:737-742.

48. Kanaya AM, Harris F, Volpato S, Perez-Stable EJ, Harris T, Bauer DC: Association between thyroid dysfunction and total cholesterol level in an older biracial population: the health, aging and body composition study. Arch Intern Med 2002, 162:773-779.

49. Eriksson P, Deguchi H, Samnegard A, Lundman P, Boquist S, Tornvall P, Ericsson CG, Bergstrand L, Hansson LO, Ye S, Hamsten A: Human evidence that the cystatin $C$ gene is implicated in focal progression of coronary artery disease. Arterioscler Thromb Vasc Biol 2004, 24:55I-557.

50. Hsu CC, Kao WH, Coresh J, Pankow JS, Marsh-Manzi J, Boerwinkle E, Bray MS: Apolipoprotein $E$ and progression of chronic kidney disease. JAMA 2005, 293:2892-2899.

51. Rule AD, Larson TS, Bergstralh EJ, Slezak JM, Jacobsen SJ, Cosio FG: Using serum creatinine to estimate glomerular filtration rate: accuracy in good health and in chronic kidney disease. Ann Intern Med 2004, 141:929-937.

52. Rule AD, Bergstralh EJ, Slezak JM, Bergert J, Larson TS: Glomerular filtration rate estimated by cystatin $C$ among different clinical presentations. Kidney Int 2006, 69:399-405.

53. Hoek FJ, Kemperman FA, Krediet RT: A comparison between cystatin $C$, plasma creatinine and the Cockcroft and Gault formula for the estimation of glomerular filtration rate. Nephrol Dial Transplant 2003, I 8:2024-2031.

54. Grubb A, Bjork J, Lindstrom V, Sterner G, Bondesson P, Nyman U: A cystatin C-based formula without anthropometric variables estimates glomerular filtration rate better than creatinine clearance using the Cockcroft-Gault formula. Scand J Clin Lab Invest 2005, 65:153-162.

55. Shlipak MG, Sarnak MJ, Katz R, Fried LF, Seliger SL, Newman AB, Siscovick DS, Stehman-Breen C: Cystatin $\mathbf{C}$ and the risk of death and cardiovascular events among elderly persons. $N$ Engl J Med 2005, 352:2049-2060.

56. Shlipak MG, Wassel Fyr CL, Chertow GM, Harris TB, Kritchevsky SB, Tylavsky FA, Satterfield S, Cummings SR, Newman AB, Fried LF: Cystatin $C$ and mortality risk in the elderly: the health, aging, and body composition study. J Am Soc Nephrol 2006, I 7:254-26I.

57. Fried LF, Katz R, Sarnak MJ, Shlipak MG, Chaves PH, Jenny NS, Stehman-Breen C, Gillen D, Bleyer AJ, Hirsch C, Siscovick D, Newman $A B$ : Kidney function as a predictor of noncardiovascular mortality. J Am Soc Nephrol 2005, I6:3728-3735.

58. O'Hare AM, Newman AB, Katz R, Fried LF, Stehman-Breen CO, Seliger SL, Siscovick DS, Shlipak MG: Cystatin $C$ and incident peripheral arterial disease events in the elderly: results from the Cardiovascular Health Study. Arch Intern Med 2005, I 65:2666-2670.

59. Shlipak MG, Katz R, Fried LF, Jenny NS, Stehman-Breen CO, Newman $A B$, Siscovick D, Psaty BM, Sarnak MJ: Cystatin-C and mortality in elderly persons with heart failure. J Am Coll Cardiol 2005, 45:268-27I.
Publish with Bio Med Central and every scientist can read your work free of charge

"BioMed Central will be the most significant development for disseminating the results of biomedical research in our lifetime. "

Sir Paul Nurse, Cancer Research UK

Your research papers will be:

- available free of charge to the entire biomedical community

- peer reviewed and published immediately upon acceptance

- cited in PubMed and archived on PubMed Central

- yours - you keep the copyright

Submit your manuscript here:

http://www.biomedcentral.com/info/publishing_adv.asp
BioMedcentral 